\title{
New records of butterflies (Lepidoptera: Papilionoidea) from the Republic of Armenia
}

\section{Новые находки дневных бабочек (Lepidoptera: Papilionoidea) из Армении}

\author{
N.H. Zarikian, M.Yu. Kalashian \\ Н.А. Зарикян, М.Ю. Кахашян
}

Scientific Center of Zoology and Hydroecology, National Academy of Sciences of Armenia, P. Sevak Str. 7, Yerevan 0014 Armenia. E-mail: noushigz@hotmail.com.

Научный центр зоологии и гидроэкологии НАН РА, ул. П. Севака 7, Ереван 0014 Армения.

Key words: Lepidoptera, Papilionoidea, fauna, new records, Armenia.

Ключевые слова: Lepidoptera, Papilionoidea, фауна, новые указания, Армения.

Abstract. Three butterfly species (Lepidoptera: Papilionoidea), Kirinia roxelana (Cramer, [1777]) from Ararat province, Melanargia grumi (Standfuss, 1892) from Kotayk province, and Zerynthia caucasica (Lederer, 1864) from Lori province are recorded for Armenia for the first time.

Резюме. Впервые для фауны Армении указываются 3 вида дневных бабочек (Lepidoptera: Papilionoidea): Kirinia roxelana (Cramer, [1777]) из Араратской, Melanargia grumi (Standfuss, 1892) из Котайкской и Zerynthia caucasica (Lederer, 1864) из Лорийской областей республики.

\section{Introduction}

Butterflies are one of the well-studied groups of insects in the Republic of Armenia. The data on country's fauna's composition can be obtained from numerous publications [Bozano, 1999, 2002; Tshikolovets, Nekrutenko, 2012; Tuzov et al., 1997; Hesselbarth, 1995; Aghababyan, Khanamiryan, 2011; Korb, Bolshakov, 2016]. According to literature sources above mentioned the butterfly fauna of Armenia can be considered as one of the most diverse among adjacent countries (Transcaucasia, Asia Minor) in spite of small territory of the country $\left(29,743 \mathrm{~km}^{2}\right)$. More than
225 species are reported for Armenian fauna, including 5 species of Papilionidae and more than 70 species of Nymphalidae.

During our study of Armenian butterflies, carried out in 2005-2016, three species from these two families were revealed in the country for the first time. The data on them are presented below. Data on general distribution are given according to publications mentioned above.

\section{Satyridae \\ Melanargia grumi (Standfuss, 1892)}

Figs 1, 4: 1 .

Material. Armenia, Kotayk province: $30^{7} 0^{7}$, env Tsaghkadzor, $40,55^{\circ} \mathrm{N}, 44,71^{\circ} \mathrm{E}, \mathrm{h} \sim 1813 \mathrm{~m}$ a.s.l., woodland clearing, 14.07.2014.

Distribution. Described from South-Eastern Turkey (type locality: «von Mardin in Kurdistan»), the species is reported from Armenia for the first time.

\section{Kirinia roxelana (Cramer, [1777])}

Figs 2, 4: 2 .

Material. Armenia, Ararat province: $20^{7} 0^{7}$, env. Khor Virap, N39 $53^{\prime}, \mathrm{E} 44^{\circ} 34^{\prime}$, h $\sim 850 \mathrm{~m}$ a.s.l., stony slopes of a hill near «Khor virap» state sanctuary, 26.04.2015.

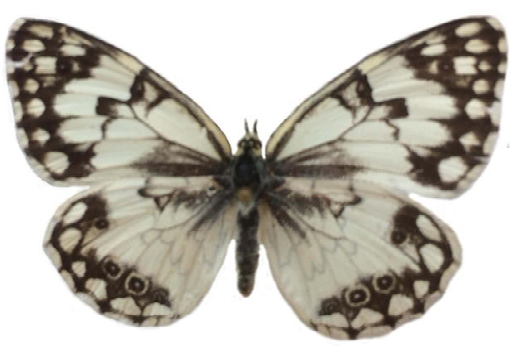

1

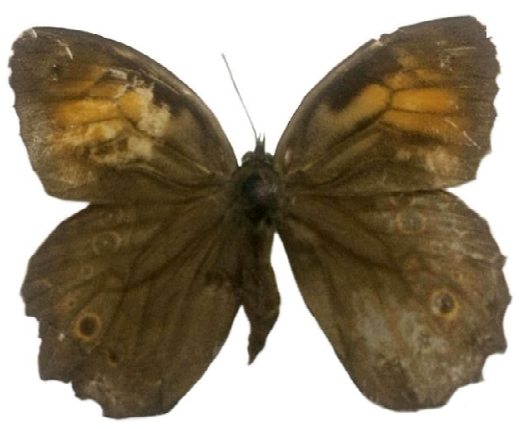

2

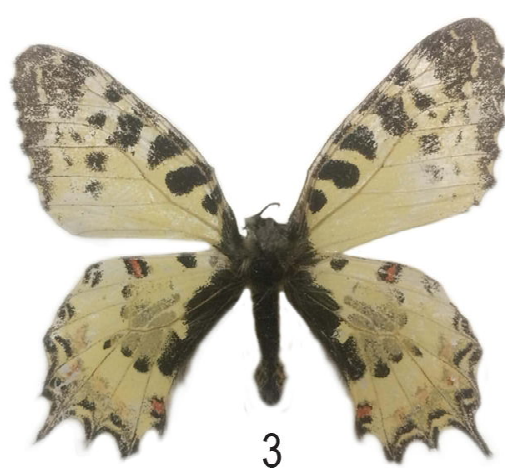

Figs 1-3. External appearance of butterflies. 1 - Melanargia grumi; 2 - Kirinia roxelana; 3 - Zerynthia caucasica. Рис. 1-3. Внешний вид бабочек. 1 - Melanargia grumi; 2 - Kirinia roxelana; 3 - Zeryntbia caucasica. 


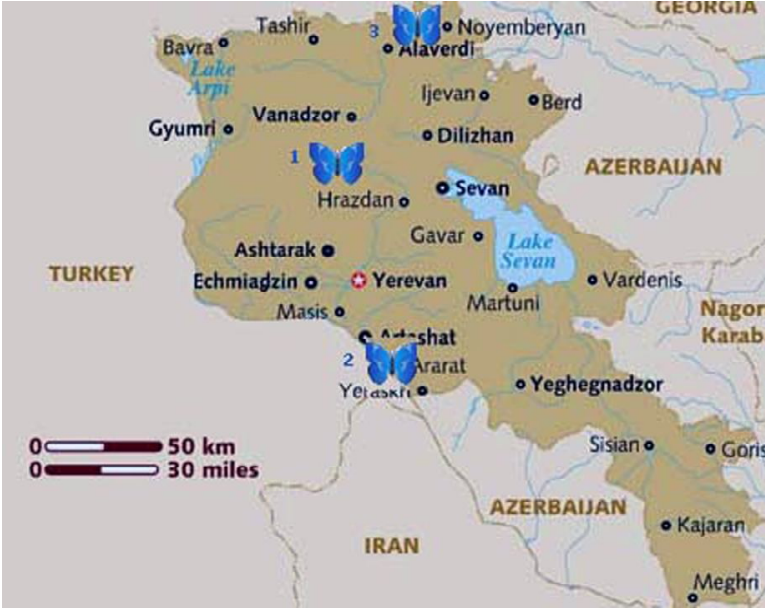

Fig. 4. Locality map of butterflies in Armenia. 1 Melanargia grumi; 2 - Kirinia roxelana; 3 - Zerynthia caucasica.

Рис. 4. Карта сборов бабочек в Армении. 1 - Melanargia grumi; 2 - Kirinia roxelana; 3 - Zerynthia caucasica.

Distribution. From south Croatia and south Romania through south Balkans and Asia Minor to West Iran and Near East; Cyprus and most of east Aegean islands.

\section{Papilionidae}

Zerynthia caucasica (Lederer, 1864)

Figs 3, 4: 3 .

Material. Armenia, Lori province: $30^{7} 0^{7}$, env. Haghpat near monastery complex, $41^{\circ} 05^{\prime} \mathrm{N}, 44^{\circ} 42^{\prime} \mathrm{E}, \mathrm{h}$ $1004 \mathrm{~m}$ a.s.l., stony clearing of woodlands, 6.05.2005.
Distribution. Southern and Eastern coasts of the Black Sea (Turkey, Georgia: described from Kutaisi), North-West and South-East foothills of the Great Caucasus.

\section{References}

Aghababyan K.A., Khanamiryan G.G. 2011. Materials for the study of the fauna of the Lepidoptera: Rhopalocera of the Meghri region of Armenia // Caucasian entomological bulletin. Vol.7. No.1. P. 69-77.

Bozano G.C. 1999. Satyridae I: Lethini. Subfamily Elymniinae, Tribe Lethini (Lasiommata, Pararge, Lopinga, Kirinia, Chonale, Tatinga, Rhaphicera, Ninguta, Neope, Lethe, Neorina) // Guide to the Butterflies of the Palearctic Region. Milano: Omnes Artes. P.17.

Bozano G.C. 2002. Satyridae III: Melanargiina and Coenonymphina Melanargia, Coenonympha, Sinonympha, Triphysa // Guide to the Butterflies of the Palearctic Region. Milano: Omnes Artes. P.14.

Hesselbarth G., Van Oorschot H., Wagner S. 1995. Die Tagfalter der Turkei unter berücksichtigung der angrenzenden länder. Goecke \& Evers (Verlag). Bdn 1-3. 1354 S.

Korb S.K., Bolshakov L.V. 2016. A systematic catalogue of butterflies of the former Soviet Union (Armenia, Azerbaijan, Belarus, Estonia, Georgia, Kyrgyzstan, Kazakhstan, Latvia, Lituania, Moldova, Russia, Tajikistan, Turkmenistan, Ukraine, Uzbekistan) with special account to their type specimens (Lepidoptera: Hesperioidea, Papilionoidea) // Zootaxa. Vol.4160. No.1. P.1-324.

Tshikolovets V., Nekrutenko Y. 2012. The butterflies of Caucasus and Transcaucasia. Tshikolovets Publications, Pardubice. P.62-70, 209-283.

Tuzov V.K., Bogdanov P.V., Devyatkin A.L., Kaabak L.V., Korolev V.A., Murzin V.S., Samodurov G.D., Tarasov E.A. 1997. Hesperiidae, Papilionidae, Pieridae, Satyridae // Guide to the Butterflies of Russia and adjacent territories. Vol.1. Sofia-Moscow: Pensoft. P.140-247. 